\title{
Effect of different Chemical Additives on growth of Azotobacter vinelandii
}

\author{
N.Mounika ${ }^{1}$ D. Muralidhara $\mathrm{Rao}^{2},{\mathrm{~A} . \mathrm{Uma}^{3}}^{3}$ and SkZ. Ali ${ }^{1}$ \\ ${ }^{1}$ Department of Microbiology, Agri Biotech Foundation, PJTSAU Campus, \\ Rajendranagar, Hyderabad-500 030, Telangana state, India. \\ ${ }^{2}$ Department of Biotechnology, Sri Krishnadevaraya University, Anantapur, Andhra \\ Pradesh, India. \\ ${ }^{3}$ Department of Biotechnology, Jawaharlal Nehru Technological University, Hyderabad, \\ Telangana state, India.
}

\begin{abstract}
:
In this experiment, we evaluated different concentrations of three different chemical amendments viz, polyvinyl pyrrolidone (PVP), gum arabica, and sodium alginate for their ability to support growth and promote survival of Azotobacter vinelandii in nutrient broth during the storage. Azotobacter vinelandiiinoculated with PVP (4\%) promoted highest cell population followed by gum arabica $(0.5 \%)$ and sodium alginate $(0.2 \%)$. The results of the present study clearly indicated that the $4 \%$ PVP probably gave higher cell population than other additives.
\end{abstract}

Key words: Additives, Azotobacter vinelandii, Cell population.

\section{Introduction}

Liquid formulations are one solution to the problems associated with solid carriers. Liquid inoculant formulations may use various broth cultures amended with agents that promote cell survival in the package and after application to seed or soil [9]. These additives to the broth can be made that will improve inoculant quality, such as including better adhesion to seed, stabilizing the product, binding or inactivating soluble seed coat toxins, and enhancing rhizobial survival during storage and after exposure to extreme environmental conditions after inoculation and seed planting. Additives to liquid inoculant formulations should have a role in protecting rhizobial cells on seed at high temperature and during desiccation. Many kinds of polymers have been used for inoculant production because of their ability to limit heat transfer, their good rheological properties and high water activities [8]. These polymers, such as methyl cellulose, gum arabic, polyvinyl pyrrolidone (PVP) and alginate are normally used as adhesive compounds with solid based carriers when they are applied to seed. Our objective is to evaluate the performance of polymeric substances that are suitable for producing quality liquid inoculant.

\section{Materials and Methods}

Microorganism used:

Azotobacter vinelandii (KT374219) isolated from rhizospheric soil of chilli plants in Rajoli, Mahboob nagar, Telangana state, India.

\section{Medium:}

Nutrient broth containing 5.0 gm peptone, $5.0 \mathrm{gm}$ $\mathrm{NaCl}, 1.50$ gm beef extract, 1.50 gm yeast extract and $\mathrm{pH} 7.4 \pm 0.2$ was used for liquid inoculant formulation with selected appropriate concentrations of additives.

\section{Screened for chemical amendments}

Nutrient broth was used in combination with different chemicals to increase the survival of Azotobacter cells. To standardize the optimum quantity of the amendments, the chemicals like PVP 1.0, 2.0, 3.0, 4.0 and 5.0\%, gum arabica 0.1, $0.3,0.5,0.7$ and $0.9 \%$ and sodium alginate 0.1 , $0.2,0.3,0.4$ and $0.5 \%$ were prepared in $250 \mathrm{ml}$ flasks containing $100 \mathrm{ml}$ of amended medium separately. Late log phase culture of Azotobacter vinelandii was inoculated individually in each 
broth and grown in shaking incubator at appropriate temperatures and 140rpm. The optical density values at $600 \mathrm{~nm}$ were recorded at $24 \mathrm{hr}$, $48 \mathrm{hr}$ and $72 \mathrm{hr}$ intervals. After 10 days of incubation period the viable cell population was determined by spread plate method. Control (without any chemical addition) was also maintained.

\section{Results \\ Effect of chemical additives on the Azotobacter vinelandii population in nutrient broth}

\begin{abstract}
The Azotobacter vinelandii showed different bacterial growth at different concentrations of additives. Significant difference was not clear.
\end{abstract}

After 10 days of incubation period the viable cell population was determined by spread plate method. Among the three different additives, PVP showed excellent viable count at 4\% (5.48 at $10^{11} \mathrm{cfu} \mathrm{m}^{-1}$ ) followed by $3 \%\left(4.20 \mathrm{cfu} \mathrm{ml}^{-1}\right.$ at $\left.10^{11}\right), 5 \%\left(3.25\right.$ at $\left.10^{11} \mathrm{cfu} \mathrm{ml}^{-1}\right), 2 \%$ (2.91 $\mathrm{cfu} \mathrm{ml}^{-}$ ${ }^{1}$ at $\left.10^{11}\right)$ and $1 \%\left(2.02 \mathrm{cfu} \mathrm{m}^{-1}\right.$ at $\left.10^{11}\right)$. After $4 \% \mathrm{PVP}$, viable count dropped. Gum arabica showed highest viable count at $0.5 \%$ (3.42 $\mathrm{cfu} \mathrm{ml}^{-}$ ${ }^{1}$ at $\left.10^{11}\right)$ followed by $0.3 \%\left(2.62 \mathrm{cfu} \mathrm{m}^{-1}\right.$ at $\left.10^{11}\right)$ followed by $0.7 \%\left(2.15 \mathrm{cfu} \mathrm{m}^{-1}\right.$ at $\left.10^{11}\right)$ and $0.1 \%$ $\left(1.82 \mathrm{cfu} \mathrm{ml}^{-1}\right.$ at $\left.10^{11}\right)$. In case of gum arabic viable count was dropped after $0.5 \%$ concentration. Sodium alginate showed better viable count at $0.2 \%\left(2.57 \mathrm{cfu} \mathrm{ml}^{-1}\right.$ at $\left.10^{11}\right)$ followed by $0.3 \%\left(1.62 \mathrm{cfu} \mathrm{m}^{-1}\right.$ at $\left.10^{11}\right)$ and $0.1 \%$ $\left(1.59 \mathrm{cfu} \mathrm{ml}^{-1}\right.$ at $10^{11}$ ) (Table 1). In case of sodium alginate viable count was dropped after $0.2 \%$ concentration. The obtained results showed excellent viable count at 4\% PVP compared to gum arabica and sodium alginate.

Table 1: Effect of polymeric additives on Azotobacter vinelandii

\begin{tabular}{|c|c|c|}
\hline Additive & $\begin{array}{c}\text { Concentration } \\
\text { of additive }\end{array}$ & $\mathrm{Cfu} / \mathrm{ml}$ \\
\hline
\end{tabular}

\begin{tabular}{|c|c|c|}
\hline \multirow{5}{*}{$\begin{array}{l}\text { Poly vinyl } \\
\text { pyrrolidone }\end{array}$} & $1 \%$ & $\begin{array}{c}2.02 \mathrm{x} \\
10^{11}\end{array}$ \\
\hline & $2 \%$ & $\begin{array}{c}2.91 \mathrm{x} \\
10^{11}\end{array}$ \\
\hline & $3 \%$ & $\begin{array}{c}4.20 \mathrm{x} \\
10^{11}\end{array}$ \\
\hline & $4 \%$ & $\begin{array}{c}5.48 \times \\
10^{11}\end{array}$ \\
\hline & $5 \%$ & $\begin{array}{c}3.25 \mathrm{x} \\
10^{11}\end{array}$ \\
\hline \multirow{4}{*}{$\begin{array}{c}\text { Gum } \\
\text { arabica }\end{array}$} & $0.1 \%$ & $\begin{array}{c}1.82 \mathrm{x} \\
10^{11}\end{array}$ \\
\hline & $0.3 \%$ & $\begin{array}{c}2.62 \mathrm{x} \\
10^{11}\end{array}$ \\
\hline & $0.5 \%$ & $\begin{array}{c}3.42 \times \\
10^{11}\end{array}$ \\
\hline & $0.7 \%$ & $\begin{array}{c}2.15 \mathrm{x} \\
10^{11}\end{array}$ \\
\hline \multirow{3}{*}{$\begin{array}{l}\text { Sodium } \\
\text { alginate }\end{array}$} & $0.1 \%$ & $\begin{array}{c}1.59 \mathrm{x} \\
10^{11}\end{array}$ \\
\hline & $0.2 \%$ & $\begin{array}{c}2.57 \times \\
10^{11}\end{array}$ \\
\hline & $0.3 \%$ & $\begin{array}{c}1.62 \mathrm{x} \\
10^{11}\end{array}$ \\
\hline
\end{tabular}

\section{Discussion:}

Additives are used as a preservatives in the preparation of liquid bioformulations, these additives improve the survivability of the cells. Additives are also used to entrap bacteria in microbeads [3], [1]. The cells cannot use these polymers as an energy source, but the polymers have other properties supporting the growth and survival of cells. They have a sticky consistency, which may enhance cell adherence to seed, and their viscous nature may slow the drying process of the inoculant after application to seed [11], [7]. In the present study, experiments were conducted to increase the survival of the liquid formulations of Azotobacter vinelandii by the addition of different polymers like gum arabic, polyvinyl pyrrolidone (PVP) and sodium alginate. In our study 4\% PVP showed excellent viable count compared to gum arabica and sodium alginate (Table 1). Liquid inoculant formulation of cowpea rhizobia prepared with PVP as an osmoprotectant been observed to have higher shelf life than those without PVP amendment [5]. PVP also has a high water binding capacity, which could maintain water around the cells for their metabolism [10], [2], [6]. Among the different chemical additives 
PVP (4\%) performed well and hence this can be used in the formulation of liquid bioinoculant.

\section{Conclusion:}

The present study supports that the isolated Azospirillum brasilense strain Asp-7 showed plant growth promoting traits, temperature and drought tolerance. After screening with different additives the polyvinyl pyrrolidone selected for the development of liquid formulation. PVP showed higher cell population of Azotobacter vinelandii.

\section{Acknowledgement:}

The authors are thankful to Rashtria Krishi Vikas Yojana (RKVY), Government of Andhra Pradesh for providing the financial assistance in the form of project on Development of liquid bio formulations.

\section{References:}

[1] Y. Bashan, J.P.0. Hernandez, L.A. Leyva, M. Bacilio, "Alginate microbeads as inoculant carriers for plant growth promoting bacteria", Biology and Fertility Soils, (35), pp. 359-368, 2002.

[2] R. Deaker, R.J. Roughley, I.R. Kennedy, "Legume seed inoculation technology - a review", Soil Biology and Biochemistry, (36), pp. 1275-88, 2004.

[3] Y.R. Dommergues, H.G. Diem, C. Divies, "Polyacrylamide-entrapped Rhizobium as an inoculant for legumes", Applied Environmental Microbiology", (37), pp. 779-781, 1979.

[4] H.C. Girisha, G.P. Brahamprakash, B.C. Mallesha, "Effect of osmo protectant (PVP-40) on survival Rhizobium in different inoculants formulation and nitrogen fixation in cowpea", GEOBIOS, (33), pp. 151-156, 2006.

[5] G. Kumaresan, D. Reetha, "Survival of Azospirillum brasilense in liquid formulation amended with different chemical additives", Journal of phytology, (3), pp. 48-51, 2011.

[6] A.E. Leo Daniel, B. Venkateswarlu, D. Suseelendra, G. Praveen Kumar, S.K.Mir Hassan Ahmed, et al., "Effect of Polymeric Additives, Adjuvants, Surfactants on Survival, Stability and Plant Growth Promoting Ability of Liquid
Bioinoculants", Journal of Plant Physiology \& Pathology, (1), pp. 2, 2013.

[7] J. Mugnier, G. Jung, "Survival of bacteria and fungi in relation to water activity and the solvent properties of water in biopolymer" Applied Environmental Microbiology, (50), pp. 108-14, 1985.

[8] T. Panlada, P. Payakaponga, N. Teaumroonga, W. Paul, B. Singleton, N. Boonkerd, "Growth, Survival and Field Performance of Bradyrhizobial Liquid Inoculant Formulations with Polymeric Additives", Science Asia, (33), pp. 69-77, 2007.

[9] P.W. Singleton, H.H. Keyser, E.S. Sande, "Development and evaluation of liquid inoculants. In: Inoculants and nitrogen fixation of legumes", in Vietnam (ed.) D Herridge, ACIAR proceedings, 109 e, pp. 52-66, 2002.

[10] F.J.Temprano, M. Albareda, M. Camacho, A. Daza, C. Santamaría, et al., "Survival of several Rhizobium/Bradyrhizobium strains on different inoculant formulations and inoculated seeds", International Microbiology, (5), 81-86, 2002. 